\title{
Constraint Management - the Review
}

\author{
Iwona Tomaszewska ${ }^{1}$
}

${ }^{1}$ Faculty of Management, Warsaw University, 02-678 Warsaw, Poland

\begin{abstract}
Constraint management has evolved into a whole system philosophy. It has a manufacture component, but the methodology focus remains at the system level. This article has presented briefly the main assumptions of Theory of Constraints (TOC), which concentrates on the process that slows the speed of production through the system. It is a simple overview of the types of constraints and tools of constraint management, looking at the background. It presents five crucial focusing steps of Theory of Constraints. It also shows the comparison TOC with Six Sigma and Lean Thinking.
\end{abstract}

Key words theory of constraints, constraint management, system as chains, lean thinking, drum-buffer-rope, five focusing steps, systems approach, goals, production scheduling, critical chain.

JEL R49, R59

\section{Brief Description of Constraint Management}

Constraint management has grown out of the Theory of Constraints (TOC), a set of principles and concepts introduced by Eliyahu M. Goldratt, an Israeli physicist, in the 1980 s in a book entitled The Goal [1, 2]. Goldratt developed three classes of tools, which will be described in detail in point 2. The theoretical principles and concepts into application was extended. In this part of the article types of constraints and assumptions of the constraint theory are presented.

\subsection{Introduction}

Theory of Constraints has evolved into a whole-system philosophy. It has a manufacture component (like for example in Lean Manufacturing) [3], but the methodology focus remains at the system level.

We define "system" in different ways. This could be the whole business, or it could be a strategic business unit, for example an independent division. It could also be one particular part in a division, though in this case some consideration of external dependencies is usually required. Goldratt characterized systems as chains. These, of course are chains of interdependency, not in the literal sense. They do not necessarily have to be a single sequence of links. The chains characterize the flow of work through the business system. Each link in the chain has a specific maximum capacity, and these capacities usually are different from one another.

Goldratt used the chain analogy to emphasize the concept of the weakest link. The strength of the entire chain is limited by the maximum strain the weakest link can stand. In the same way, the performance of a sequential flow system is limited by the least capable element of this system. The weakest link can occur anywhere in the chain of dependency. For example, limited capacity on a piece of manufacturing equipment might restrict output or sales might not be sufficient to fill up available capacity. In the first situation, the performance of the whole company (system) is limited by a physical resource. In the second, it is limited by external demand [4]. The strength of the chain is determined by the strength of its weakest link. The research shows that there is only one weakest link in a chain.

\subsection{Types of Constraints}

Identifying and breaking constraints become easier if there is an orderly way of classifying them. As it is known system constraints can be considered of two types - physical one and political one. Within these two broad categories, there are seven basic types of constraints [5]:

1. market - not enough demand for a product or service.

2. resource - not enough people, equipment, or facilities to satisfy the demand for products or services.

3. material - inability to obtain required materials in the quantity or quality needed to satisfy the demand for products or services.

4. supplier/vendor - unreliability (inconsistency) of a supplier or vendor, or excessive lead time in responding to orders.

5. financial - insufficient cash flow to sustain an operation. For example, a company that cannot produce more until payment has been received for work previously completed, because they might need that revenue to purchase materials for a firm order that is waiting.

6. knowledge/competence - knowledge: information or knowledge to improve business performance is not resident within the system or organization. 
Competence: people do not have the skills necessary to perform at higher levels required to remain competitive.

7. policy - any law, regulation, rule, or business practice that inhibits progress to-wards the system's goal.

\subsection{Four Assumptions of Constraint Theory}

The Theory of Constraints is based on four assumptions, which are TOC principles and prescriptions for plenty of organizations as a system because [5]:

1. every system has a goal and necessary conditions that must be satisfied in order to achieve it. Effective effort to improve system performance is not possible without a clear understanding and consensus about what the goal and necessary conditions are.

2. the system optimum is not the sum of the local optima (efficiencies). In other words, the most effective system does not come from maximizing the efficiency each system component individually, without regard to its interaction with other components.

3. very few variables maybe only one-limit the performance of a system at any given time: This is equivalent to the "weakest link" concept discussed earlier.

4. all systems are subject to cause-and-effect. There are natural and logical consequences to any action, decision, or event. For these events that have already occurred, these consequences can be visually mapped to aid in situation or problem analysis. For those decisions that have yet to occur, or which are contemplated, the outcomes of these actions, decisions or events can be logically projected into the future and visually mapped.

The first presented above assumption states that every system has a goal and a set of necessary conditions that must be satisfied to achieve that goal. The most for-profit companies have something financial as their goal. Goldratt argues that the goal of for-profit companies is to "make more money, now and in the future". This, of course, would not be an appropriate goal for a government agency and therefore non-financial goals would have to be developed for such agencies. But it works quite well for most companies engaged in commercial business.

The importance of identifying a system (that means organization) is goal and necessary conditions become the standard by which all results are judged and all contemplated decisions are evaluated link. The organization knows that it is making progress in the right direction.

\section{Tools of Constraint Management}

A constraint management philosophy developed by Goldratt can be viewed as three separate but interrelated areas: logistics, performance measurement, and logical thinking. Logistics include drum-buffer-rope scheduling, buffer management, and VAT analysis. Performance measurement includes throughput, inventory and operating expense, and the five focusing steps. Thinking process tools are important in identifying the root problem (current reality tree), identifying and expanding win-win solutions (evaporating cloud and future reality tree), and developing implementation plan (prerequisite tree and transition tree).

To manage a system using the constraint philosophy, Goldratt created four functional tools: The five focusing steps for system improvement and The logical thinking process. This thinking process is unique problem-solving methodology that goes beyond problem identification and solution generation to verify and implement planning. $\mathrm{He}$ conceived drum-buffer-rope, a finite-capacity production management methodology. He created a scheduling tool called critical chain for project management environments.

\subsection{The Five Focusing Steps}

Theory of constraints (TOC) focuses on system improvement. A system is defined as a series of interdependent processes. An analogy for a system is the chain: a group of interdependent links working together toward the overall goal. The constraint is a weak link. The performance of the entire chain is limited by the strength of the weakest link. TOC concentrates on the process that slows the speed of product through the system. Below are the Five Focusing Steps of TOC which are explained in more detail in "The Goal" books $[1,6]$ :

1. identify the constraint of the system. The amount of work in queue ahead of a process operation is a classic indicator. Another example is where products are processed in batches.

2. decide how to exploit the constraint of the system. Once the constraint is identified, the process is improved or otherwise supported to achieve its utmost capacity with-out major expensive upgrades or changes. In other words, the constraint is exploited.

3. subordinate everything else to the decision in step 2 . When the constraining process is working at maximum capacity, the speed of other subordinate processes is paced to the speed or capacity of the constraint. Some processes will sacrifice individual productivity for the benefit of the entire system. Subordinate processes are usually found ahead of the constraint in the value stream.

4. elevate the system's constraint. If the output of the overall system is not satisfactory, further improvement is required. Changes can involve capital improvement, reorganization or other major expenditures of time or money.

5. repeat means go back to step 1, but do not allow "inertia" to cause a system constraint. Once the first constraint is broken, another part of the system or process chain becomes the new constraint. Now is the time to repeat the cycle of improvement.

\subsection{The Logical Thinking Process}

The Theory of Constraints usually applies to running and improving an organization. It consists of Problem Solving and Management/Decision-Making Tools called the Think- 
ing Processes (TP). TOC is applied to answer three questions essential to any process of ongoing improvement logically and systematically:

- What to change?

- To what to change?

- How to cause the change?

TOC postulates that the goal is to make money. It describes three ways to achieve this goal:

- Increase Throughput

- Reduce Inventory

- Reduce Operating Expense

\subsection{Drum - Buffer - Rope production scheduling}

Probably the best-known of the constraint management tools developed by Goldratt is called "Drum-Buffer-Rope" (DBR). The analogy was a description of a boy scout hike [1].

The drum was the pace of the slowest boy scout, which dictated the pace for the others. The buffer and rope have an additional meaning to ensure all the boy scouts walked at approximately the pace of the slowest boy. In a manufacturing or service company, the "drum" is the schedule for the resource or work center with the most limited capacity: the capacity constrained resource.

Starvation can result from upstream process variability, which might delay the transfer of work-in-process beyond its expected time. To ensure the capacity constrained resource is not starved for work, a buffer time is established to protect against variability. This is a period of time in advance of the scheduled "start processing" time that a particular job arrives at the capacity constrained resource.

The rope is constraint management's safeguard against overloading the capacity constrained resource. In essence, it is a material release schedule that prevents work from being introduced into the system at a rate faster than the capacity constrained resource can process it. The rope concept is designed to prevent the backlog of work at most points in the system. This is important because work-in-process queues are one of the chief causes of long delivery lead times.

When the entire Drum-Buffer-Rope concept is applied, delivery reliability of 100 percent is not an unreasonable target and time of the process is reduced by 70 percent.

\subsection{Critical Chain}

Another valuable asset in the constraint management toolbox is called "critical chain". Critical Chain is also the title of the book by Goldratt [7]. Critical chain, is the first innovation in the field of project management in 50 years, and is ideally suited for high-uncertainty projects.

The critical chain concept provides an effective way to schedule the project activities by effectively accommodating uncertainty and resolving simultaneous needs contentions for the same resource. Critical Chain constitutes the application to onetime pro-jects of the same principles that Drum-Buffer-Rope applies to repetitive production [8]. The result of applying Critical Chain scheduling and resource allocation is a higher prob-ability of completing projects on time, and, in some cases, actually shortening total project duration. Originally applied to the management of a single project, the Critical Chain method has been expanded to multi-project environments, based on the concept of the "drum", described in Drum-Buffer-Rope.

Critical Chain tool has an input to make next edition the Project Management Body of Knowledge. Look at the distinguishes of Critical Chain from PERT/CPM and other traditional project management approaches presented below:

Critical Chain recognizes and accounts for some human behavioral phenomena that traditional project management methods do not. These phenomena include $[9,10]$ :

1. the tendency of technical professionals to "pad" their time estimates for individual tasks, in an effort to protect themselves from late completion.

2. "student syndrome" - waiting until the last minute to start working on a task with a deadline.

3. Parkinson's Law - ensuring that an activity consumes every bit of the estimated time, no matter how quickly the associated tasks can actually be completed).

4. multitasking - the tendency of management to assign people more than one deadline activity simultaneously. Multitasking can create a devastating effect.

To solve this problem, Critical Chain takes most of the protective time out of each individual activity and positions some of it at key points in the project activity network: at convergence points and just ahead of project delivery. Since accumulating protection on an entire chain is much more effective than protecting every activity, only half of the aggregated "protective pad" extracted from individual activities is put back in at the key locations. The rest can contribute to earlier project completion. In traditional project execution, if protective time in a specific activity was not used, it would be lost forever - unusable by later activities that might need more protection than they were originally assigned. This formerly "lost time" is, in many cases, usable in Critical Chain.

Critical Chain devotes more attention to the availability of critical resources when they are needed for specific activities. Leveling the resources on any single project is mandatory [11]. The Critical Chain is really the longest sequence in the project that con-siders both dependent, sequential activity links and resource links. The critical path reflects only the sequential linking of dependent tasks.

\section{Comparison TOC with Six Sigma and Lean Thinking}

This part of article will focus on the basic ideas concern three improvement methodologies and will show a model to present their concepts, effects, similarities and differences. Table 1 describes the essence of each methodology. The Six Sigma and Lean thinking philosophies will be presented briefly, for sake of comparison, while Theory of Constraints 
(TOC) the author has described in more detail above.

Six Sigma claims that focusing on reduction of variation will solve process and business problems. By using a set of statistical tools to understand the fluctuation of a process, management can begin to predict the expected outcome of that process. If the outcome is not satisfactory, associated tools can be used to understand the elements influencing that process further $[12,13]$.

Lean thinking is sometimes called lean manufacturing, the Toyota production system or other. Lean thinking emphasizes on the removal of waste, which is defined as anything not necessary to produce the product or service. One common measure is touch time - the amount of time the product is actually being worked on, or touched by the worker. Frequently the focus of lean thinking is manifested in an emphasis on flow $[14,15,16]$.

There are five essential steps in lean thinking: identifying which features create value, identifying the sequence of activities called the value stream, making the activities flow, letting the customer pull product or service through the process and perfectly the process.

Table 1. The essence of each methodology (SixSigma, Lean Thinking and Theory of constraints (TOC) [13]

\begin{tabular}{|c|c|c|c|}
\hline Program & Six Sigma & Lean thinking & Theory of constraints \\
\hline Theory & Reduce variation & Remove waste & $\begin{array}{c}\text { Manage } \\
\text { constraints }\end{array}$ \\
\hline $\begin{array}{l}\text { Application } \\
\text { guidelines }\end{array}$ & $\begin{array}{c}\text { Define } \\
\text { Measure } \\
\text { Analyze } \\
\text { Improve } \\
\text { Control }\end{array}$ & \begin{tabular}{|c} 
Identify value \\
Identify value stream \\
Flow \\
Pull \\
Perfection
\end{tabular} & $\begin{array}{l}\text { Identify constraint } \\
\text { Exploit constraint } \\
\text { Subordinate processes } \\
\text { Elevate constraint } \\
\text { Repeat cycle }\end{array}$ \\
\hline Focus & Problem focused & Flow focused & Systems constraints \\
\hline
\end{tabular}

\section{REFERENCES}

[1] Goldratt, E. M., Cel I - doskonałość w produkcji, Mint Books, Warszawa 2007.

[2] Goldratt, E. M., Fox R., The Race, Croton-on-Hudson, The North River Press, Nowy Jork 1986.

[3] Bednarek M., Doskonalenie systemów zarządzania. Nowa droga do przedsiębiorstwa lean, Difin, Warszawa 2007.

[4] Dettmer W. H., Beyond Lean Manufacturing: Combining Lean and the Theory of Constraints for Higher Performance, $\mathrm{http} / /$ www.tocca.com.au/uploaded/documents, 27.05.2009 r.

[5] Schragenheim E., Dettmer W. H., Manufacturing at Warp Speed: Optimizing Supply Chain Financial Performance, Boca Raton, FL: St. Lucie Press, 2000, http://www.amazon.com/Manufacturing-Warp-Speed-Perfor manceConstraints/dp/1574442937, 27.05.2009 r.

[6] Goldratt, E. M., Cel II - to nie przypadek, Mint Books, Warszawa 2007.

[7] Goldratt, E. M., Łańcuch krytyczny, Werbel, Warszawa 2000.
[8] Critical Chain Buffer Management. Taming Uncertainty in Project Operations, www.pinnacle.com, 02.05.2008 r.

[9] Dettmer W. H., Goldratt's Theory of Constraints: A Systems Approach to Continuous Improvement, Milwaukee: ASQ Quality Press, 1997, www.goalsys.com, 04.03.2009 r.

[10] Dettmer W. H., Constraint Management, Quality America, Inc., 2000, www.goalsys.com, 04.03.2009 r.

[11] Schragenheim E., Dettmer W. H., Simplified Drum-Buffer-Rope A whole System Approach to High Velocity Manufacturing, Quality America, Inc., 2000, www.goalsys.com, 04.03.2009 r.

[12] Vitalo, R., Six Sigma and Kaizen Compared: Part 1 (Revised), Vital Enterprises, http://www.vitalentusa.com/learn/6-sigma_vs_kaizen_1.php, 26.05.2009 r.

[13] Nave D., How To Compare Six Sigma, Lean and the Theory of Constraints, http://www.lean.org/Community/Registered/ArticleDocume nts/ASQStoryonQualitySigmaAndLean.pdf, 26.05.2009 r.

[14] Bednarek M., Stałe usprawnianie zarządzania jako podstawowe narzędzie poprawy pozycji konkurencyjnej przedsiębiorstw, Wyższa Szkoła Humanistyczno-Ekonomiczna, Łódź 2002.

[15] Grudzewski W., Hejduk I., Metody projektowania systemów zarządzania, Difin, Warszawa 2004.

[16] Grudzewski W., Hejduk I., Wpływ technologii na przedsiębiorstwo przyszłości, Difin, Warszawa 2000. 